\title{
The Revival of Adat and the Articulation of the 'Kingdom Slot' in Loloda, North Halmahera, Indonesia
}

\author{
Seung-Won Song \\ Hankuk University of Foreign Studies, Yongin, South Korea \\ swsong@hufs.ac.kr \\ Mustafa Mansur \\ University of Khairun, Ternate, Indonesia \\ mustafa.mansur8@gmail.com
}

\begin{abstract}
This article examines the historical background behind the recent reinstallation of Loloda's kingship in North Halmahera, Indonesia. This marginalized group of people reignited their mythic narratives to renegotiate their centrality and power as a region, strengthening both their ethnic and cultural identities in the process. Through the narrative of the Kie Romtoha (Five Mountains), the activists placed Loloda alongside the four other mythic centres of Maluku called the Kie Raha (Four Mountains) and promoted the myth of Jou Tolo, a royal ancestor, to conform with the royal origin stories of the Kie Raha states. This article illustrates how the Loloda people were not only able to rise above their societal position by rearticulating these myths, but were also able to utilize these stories to facilitate religious reconciliation in modern times, despite there being a painful history of division between Muslims and Christians within this community.
\end{abstract}

\section{Keywords}

Loloda Kingdom - Kie Romtoha - Jou Tolo - North Halamhera - adat revival 


\section{Introduction}

This article aims to investigate how the people of Loloda in North Halmahera, Indonesia, anticipated the constructive role of the nominal kingship that they revived in 2016 as part of the process of adat (traditional customs) revivalism. Specifically, it examines how the local adat activists articulated mythic narratives as the basis of their discourses, which served to confer historical legitimacy for the revived kingship that had disappeared a hundred years ago.

Adat can simply mean traditional customs and customary laws, but the kind of adat that the Loloda activists anticipated reviving is closer to Taufik Abdullah's definition of the term as 'the entire value system, the basis of all ethical and legal judgment, as well as the source of social expectations', which represents 'the ideal pattern of behaviour' (Abdullah 1966:1; quoted in Jäger 2018:4). By the time of Sukarno's presidency (1945-1967), adat as political and social institutions of traditional domains had become decontextualized, although the village adat system remained operational to a limited degree without formal legal recognition. During Soeharto's rule (1967-1998), adat was revived as folklore, art, and culture to promote local tourism. In the decentralized Reformasi era after Soeharto's downfall, many Indonesians began to redeploy adat to strengthen ethnic identities in a collective act of indigenous people's empowerment against the modern nation-state with regard to issues of land or autonomous governance. ${ }^{1}$

The people of Loloda recalled the former subjects of the Loloda Kingdom (which existed from around the thirteenth century up to 1909), which was located at the northern tip of Halmahera. European records reveal that the kingdom was lost even before the Europeans arrived (Andaya 1993b:51-2). Yet, the villagers continued to call a poor Muslim fisherman the kolano (king) until the last one was deposed by the Dutch colonial government in the early twentieth century, thereby claiming that their kingdom had been sustained over time. In the contemporary period, the collective memories of the kingdom and its adat were almost lost and its ethnic identity weakened (see Figure 1).

In understanding the reconstruction of adat and the ethnic identity in Loloda, concepts of articulation and positioning proposed by Stuart Hall (1986, 1996) are useful. Hall criticizes Eric Hobsbawm's concept of 'invention of tradition', according to which 'traditions which appear or claim to be old are often quite recent in origin and sometimes invented' (Hobsbawm 1983:1). Hobsbawm's theory has been criticized for setting up 'a false dichotomy between

1 Duncan 2009; Hauser-Schäublin 2013; Henley and Davidson 2008; Tyson 2010. 


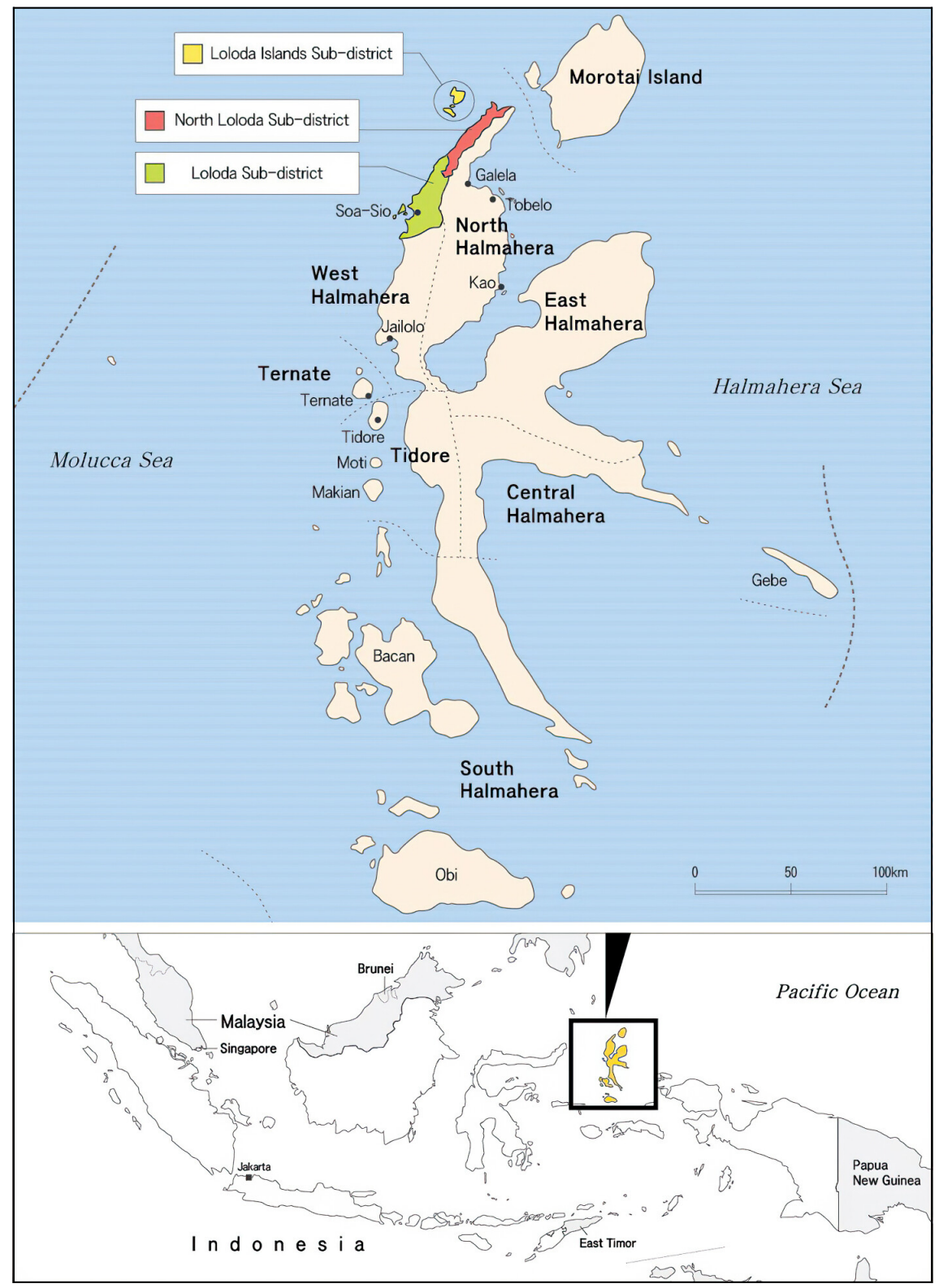

FIGURE 1 Halmahera map (Inset: map of Indonesia showing Halmahera) (C)AUTHORS, 2019 
tradition, that which is invented and thus inauthentic, and custom, that which is autochthonous and thus more authentic' (Duncan 2009:1080). In explaining the effort to reconstruct an identity, Hall argues that it is drawn from real but separate, unrelated traditional elements, and is 'not an essentialist, but a strategic and positional one', wherein the question of authenticity is secondary (Hall 1996:3; see also Hall 1986; Clifford 2001). Grossberg (1996:141-2) summarizes Hall's concept of articulation as follows:

An articulation is thus the form of the connection that can make a unity of two different elements, under certain conditions. It is a linkage which is not necessary, determined, absolute and essential for all time. You have to ask, under what circumstances can a connection be forged or made? So the so-called 'unity' of a discourse is really the articulation of different, distinct elements which can be rearticulated in different ways because they have no necessary 'belongingness'. The 'unity' which matters is a linkage between that articulated discourse and the social forces with which it can, under certain historical conditions, but need not necessarily, be connected. Thus, a theory of articulation is both a way of understanding how ideological elements come, under certain conditions, to cohere together within a discourse, and a way of asking how they do or do not become articulated, at specific conjunctures, to certain political subjects.

$\mathrm{Li}$ (2000) adopted the concept of articulation in analysing the contemporary reconstruction of the ethnic identity of the upland people at Lindu in Sulawesi. Li saw that their 'true' identity was closer to that of simple village folk (I. orang kampong) who are not strongly distinct in terms of ethnicity. Yet, the villagers articulated a 'tribal slot' as a way of empowering themselves against the nation's exploitative development projects. Nevertheless, this identity as an 'isolated tribe' (I. masyarakat terasing) was not simply invented, adopted, or imposed but created by a 'positioning which draws upon historically sedimented practices, landscapes, and repertoires of meaning, and emerges through particular patterns of engagement and struggle' (Li 2000:151).

Drawing inspiration from Li's use of the concept of 'tribal slot', we use the term 'kingdom slot' to explain the adat revival in Loloda. The Loloda activists mobilized the 'kingdom slot', even though the people were generally described by the Dutch colonizers as alifuru, or 'untamed', animist people. Although there are scattered memories of their kolano, the region was only an aggregation of multiple villages, which made the kolano closer to a humble chief who ruled over a few clans than a king. Yet, the adat activists rendered a collective identity 
for the people of Loloda as the former subjects of a great kingdom by drawing repertoires of meanings from vaguely remembered pasts and mythic narratives that emphasized the centrality of its kingdom.

The revived adat of Loloda was also meant to serve as a platform for religious reconciliation between its Muslim and Christian populations, which were devastated after the 1999-2002 North Maluku Conflict. The adat activists articulated the royal-origin myth, which falls into the category of 'stranger-kingship' frequently found in the Austronesian-speaking world, including the eastern part of Indonesia (Sahlins 1985; Fox and Sather 2006). Although this myth does not directly address Muslim-Christian relations, the adat activists articulated the diarchic elements in the myth as a common platform for religious reconciliation. The diarchic element also substantiated a well-established claim that their kingship was democratic in nature, a requisite for the parallel existence of its feudal leadership (albeit symbolic) and republic order. Through such articulation, these activists tried to reanimate traditional notions of sovereignty and cosmogony that have undergone transformation through modern and contemporary histories.

In analysing Loloda's adat discourses and rituals, we suggest that these were not their unique constructions but were largely drawn from neighbouring regions, particularly Ternate and Jailolo. Yet, Loloda's adat activists rearticulated or de-articulated these discourses in such regions to conjoin them with their distinct interests.

This article examines how the adat activists in Loloda articulated historical and mythic elements to construct adat discourses and rituals. Multiple questions will be addressed, including: Under what socio-political circumstances did the activists choose the kingdom slot as their regional and ethnic identity, and how did such an identity fit with their 'authentic identity'? Who were the adat activists, and what social needs gave rise to this ethnic revivalism? How did Ternate's and Jailolo's adat discourses and practices influence the Loloda adat discourses? How did the activists synthesize mythical and historical elements to reformulate their ethnic identity? How did the stranger-kingship myth provide a platform for religious reconciliation?

The authors, Seung-Won Song and Mustafa Mansur, first met in Ternate, when the former was conducting her own research on the origin myths of North Maluku in 2018. Mustafa, a native historian of Loloda who is affiliated with the University of Khairun in Ternate, was involved in the revival of Loloda's history and kingship in 2016. While discussing the origin myths of North Maluku, both authors became interested in writing a comparative analysis of the adat revival movements in the region. This led to the decision to conduct ethnographic research in, and co-author an article on, Loloda. The collaborative research 
was conducted from 2018 to 2019 in the three villages of Soa-Sio, Bakun, and Kedi. The resulting article is based on the extensive data provided not only by Mustafa but also by numerous other informants in Loloda, Ternate, Tidore, and Jailolo, who are knowledgeable about the meanings of the adat revival process. The major interviewees include key adat figures of Loloda, such as Suaib Syamsudin (kolano), Habib Mamang (jogugu), Djae Syamsudin (the imam or Islamic leader of Soa-Sio), village elders (Heres Lalomo, Yopi Luwo, Yonatan Tuka, and Titus Moraka), local intellectuals including Aman Samsudin (head of the Loloda subdistrict), Rusdi Maxsud (village head of Soa-Sio), Stevan Taliawo (local politician), and numerous others. The adat figures in other regions, such as Amin Faaroek ( jojau of the Tidore court), Haerufdin Saefudin (jogugu of the Jailolo court), and Jadad (kimalaha lia of the Jailolo court) also provided valuable information. ${ }^{2}$

This article is structured in five parts. The first part provides a brief overview of Loloda, while the second section explains the goals for reviving the kingship. The third part explores the adat discourses of Ternate and Jailolo in order to understand how they affected the adat revival in Loloda; the fourth delves into how the activists articulated the myths; and the fifth segment explains how the mythic traditions were associated with the kolano's inauguration rituals.

\section{Brief Overview of the Region and Its History}

While the exact year of the kingdom's creation is unknown, local people claim that Loloda is the oldest kingdom in Maluku and that it has existed since the early thirteenth century. The root of loda in Loloda is from the Galela language and means 'to flee' (Baarda 1904:319). Lalomo, an elder of the Bakun Village, told us that a lord of Galela, named Jou Tolo, fled to Loloda to escape a volcanic eruption. Currently, the traditional territories of the kingdom are divided into three subdistricts (I. kecamatan), including Loloda, Loloda Utara (North Loloda), and Loloda Kepulauan (Loloda Islands). ${ }^{3}$ While the Loloda subdistrict belongs to the Kabupaten Halmahera Barat (West Halmahera District), North Loloda and Loloda Islands belong to the Kabupaten Halmahera Utara

2 We would like to thank all our informants for allowing us to use their real names in this article. The titles of jogugu / jojau and kimalaha lia are the adat equivalents to prime minister and minister of internal affairs, respectively.

3 Recently, a new subdistrict of Central Loloda (Loloda Tengah) was separated off from the Loloda subdistrict, but since the administrative office is not yet functional, it remains subject to the control of the latter. 
TABLE 1 Religious population of the Loloda Region

\begin{tabular}{lrrrr} 
Sub-districts & Muslims & Protestants & Catholics & Total population \\
\hline Loloda & 2,865 & 11,416 & 231 & 14,512 \\
North Loloda & 2,889 & 6,181 & 11 & 9,081 \\
Loloda Islands & 7,193 & 819 & 0 & 8,012 \\
Total & 12,947 & 18,416 & 242 & $31,6 \circ 5$ \\
\hline
\end{tabular}

BPS Kabupaten Halmahera Barat and Utara 2017

(North Halmahera District). The traditional administrative centre is called the Soa-Sio, which belongs to the Loloda subdistrict. This is the new settlement of Soa-Sio; the original one, which was located upstream of the Soa-Sio River, was abandoned after the centre was moved to its current location near Kedi Harbour after World War II. In 2016, the total population of the three Loloda subdistricts was around 31,605. Among these, Muslims comprised approximately $41 \%$, while Christians (mostly Protestants) accounted for the rest (see Table 1).

The people of North Maluku began to form a supra-ethnic identity based on their mythos of a 'sacred unity' that existed before the arrival of the Europeans (Andaya 1993b). According to their cosmogony, there were four exemplary centre states, called the Kie Raha (Four Mountains), and numerous peripheral states in Halmahera, Papua, and Sulawesi. They were bound by familial relationship through multiple-origin myths (Andaya 1993b:47-112). The Kie Raha included Ternate, Tidore, Jailolo, and Bacan, while Banggae (Banggai), Raja Ampat of Papua, and many other small states, including Loloda, belonged to peripheral territories (Andaya 1993b:82-112). The Kie Raha emerged as centres of authority due to the flow of wealth from the sale of cloves, which was native to a handful of islands of North Maluku.

Most of the Loloda Kingdom's history before the nineteenth century is veiled in mystery, as historical records are sparse. According to European sources, during the rule of António Galvão, the Portuguese governor of Maluku (1536-1540), Loloda was a small, village-sized area. However, people called an impoverished man the kolano. He lived with his mother in the Muslim village of Soa-Sio (before it was relocated), which was surrounded by five alifuru villages. The kolano had no slaves, and hence, while his mother did all the household chores, he had to work to feed himself by cultivating coconut trees, fishing, and hunting (Andaya 1993b:93). However, most of the adat activists of Loloda explained that the territories under the authority of the kolano extended further, although 
the European records had downsized the kingdom to an area only as big as a village. Therefore, they argued, the kolano were more respected than the raja, referring to the village heads in South and Central Maluku. According to some fragmented historical records and public memories, the Loloda Kingdom was attacked by Spanish merchants in the early seventeenth century and eventually placed under the suzerainty of Ternate, which emerged as a powerful overlord in northern Halmahera (Platenkamp 2013; Andaya 1993b: 4-98). Sultan Hamzah (1627-1648) of Ternate launched an expansionist policy and drove a massive evacuation of Loloda people to Jailolo, which resulted in a rapid decline in the population (Andaya 1993b:159).

Platenkamp (2013:209) explains that the relationship between the Sultanate of Ternate and its dependencies overseas represented 'a sovereign whole in its own right, which was grounded in specific social and cosmological representations'. The name Soa-Sio reflected the influence of this powerful relationship, as it referred to Ternate's administrative centre. ${ }^{4}$ Ternate established some representatives for its dependencies, such as kimalaha (lit., noble person), ngofamanyira (lit., eldest child), and hokum (judge), who were stationed in Soa-Sio. These districts were divided with each having a separate autonomous ruler, called a sangaji, who headed the district while acknowledging Ternate's sovereignty and paying tributes levied by the Ternate sultans (Baarda 1904:320; Andaya 1993b:83-98; Platenkamp 2013:211).

By the early twentieth century, Loloda's population still did not exceed 3,00o men (Baarda 1904:320). Some of the villages in the 189os were described by De Clercq (1999:74), a Dutch resident of Ternate, as follows:

The residence of the Rajah lies one-half hour's rowing time from the coast. [...] Lolodah [Loloda] is divided into three Alfuru [alifuru] kampongs [villages], Bakunu [Bakun], Loba [Laba], and Kedi, and two Islamic ones, Soahsio [Soa-Sio] and Bantoli. ${ }^{5}[\ldots]$ The Rajah annually receives from the Alfuru population a certain quantity of rice. The only Ternatese officials here are a Jurtulis (scribe), three helpers and a kabo [an associated official at the sangaji's domain], whose services can be bought for twelve reals annually. To the north is another small kampong called

4 The soa is an elementary territorial unit found in large parts of North Maluku. It consists of patrilinear groups of descent sharing common ancestors (Jäger 2018:50).

5 De Clercq, in this quote, notes that there were two Muslim villages, Soa-Sio and Bantoli. Yet, Bantoli was one of the nine soa (clan) comprising the Soa-Sio (lit., nine soa). From this, one may infer that as Bantoli was located farther away from Soa-Sio, it was regarded by De Clercq as a separate village. 
Ngajam or Ngacam. Besides rice and maize plantations, there are sago forests and coconut plantations everywhere. [...] To the north, Lolodah stretches as far as the kampong Supu in the district of Galela [...] The socalled orang gorap live on the coast in numerous small settlements such as Pocau, Diti, Gamkahe, Bartako, and others. These people came originally from Manggarai on Flores, Salayer, and Buton, but were captured by pirates from Halmahera and put ashore here. They are commonly known in these regions as orang baharu, and are directly under the command of the Rajah, without interference from the Ternatese authorities.

As mentioned above, unlike other districts in Halmahera, the kolano of Loloda acted as an independent ruler and received various services from several alifuru villages (see also Baarda 1904:320). While the Loloda people were generally perceived by Dutch colonizers as alifuru, a small number of Muslims lived in the capital of Soa-Sio. Concerning the religious division of this region, it is interesting to note that the Muslims were the aristocrats, while the alifuru were the commoners. The Muslim aristocrats were descendants of a royal ancestor who had formed an immigrant group (a stranger-king group), and thus Soa-Sio became the enclave of a Muslim immigrant population.

To understand the relationship between the Muslim stranger-king and alifuru autochthons, it is useful to examine debates among scholars about the nature of the stranger-kings. Henley (2002:65), for instance, argues that the tradition of inviting stranger-kings was perceived by the locals as 'stylized and idealized solutions $[\ldots]$ to the problem of finding a head of state who does not himself provoke destructive jealousy and rivalry', and who would be an objective arbitrator and judge. Sahlins (2008) also mentions that the strangerkings brought new order and prosperity along with the arts of civilization while preventing social ills caused by the preservation of consanguineal kindred. Nourse (2008), however, saw stranger-kings in the upland Lauje of Sulawesi as a 'necessary evil', who protected people from invading raiders by being arbitrators based on their ability to speak Malay. Yet, they sought economic gains by exploiting the local population, who described them as 'rogue kings'. In the case of Loloda, the alifuru villagers did not perceive the Muslim king as an outsider or exploiter, although some oral sources revealed that one kolano (the name unknown) was brutal, and hence, the people moved to the eastern Sahu subdistrict and established the village of Gamsungsi.

Djae Syamsudin, a Muslim leader (imam besar) of Soa-Sio, revealed in a personal interview a few reasons for the non-Islamization of the commoners, mainly mentioning the fear of circumcision. Most importantly, however, it was considered a deliberate strategy of the noble group, as they considered Islam a 
symbol of civilization and modernity, and thus, an important social marker of ranks. To maintain hierarchical supremacy, the nobles wanted the commoners to remain alifuru, while Islam remained exclusive to them.

Later, the alifuru commoners began to be targeted for Christianization with the advent of the European missionaries. In the sixteenth and seventeenth centuries, Roman Catholic missionaries from Portugal and Spain attempted to spread Christianity in Halmahera (Andaya 1993b:122-32). However, the Utrechtsche Zendingsvereeniging (UZv), a Dutch Protestant missionary organization in Loloda, began to Christianize the population there. According to Amien Faaroek, a court official ( jojau) in Tidore, the missionaries had initially gone to Ternate and Tidore to ask the sultans whether they could Christianize the population, but the sultans had advised them to set up missions in Halmahera and Papua instead. Even though the kolano of Loloda attempted to deter the efforts to Christianize the people, the missionaries simply insisted that they had been authorized by the sultans to perform their work and continued working at their missions. Van Baarda, a UzV missionary-cum-anthropologist, arrived in Loloda around 1896 and constructed a church in the northern village of Dorume, and 70 people accepted baptism (A. Rahman 2015:101). After World War II, the local missionaries from the Gereja Masehi Injil Halmahera (Evangelical Church in Halmahera) resumed their expansion of the mission.

The Loloda Kingship vanished with the displacement of the last kolano, Syamsudin, as a result of the 1909 rebellion (the Laba War or Perang Laba) led by Sikuru of the village of Laba. The community was opposed to the Dutch tax system and forced labour, and the Laba War resulted in the death of a few Dutch tax officers and some policemen. The kolano was charged as being responsible for the incident, and perhaps he was also denounced for his efforts to deter Christianization. He was dismissed by the colonial government in 1909 and exiled to Ternate, where he died in 1915. Like Jailolo and many other small kingdoms in Halmahera, Loloda became a district under Ternate's suzerainty (Mansur, Sofianto, and Mahzuni 2013:65). In 1930, the Dutch colonial government divided North Maluku into three swapraja (self-governed regions or districts) called Kesultanan Ternate, Tidore, and Bacan. Loloda belonged to the swapraja Ternate, and this district system continued until 196o. After a brief period of Japanese rule (1942-1945), Loloda was integrated into the Indonesian Republic in 1945 .

Even after the last kolano died, traditional authority was retained, because in 1945 the sultan of Ternate appointed the kolano's son, Djamilullah bin Syamsudin, as the jogugu (prime minister). By calling him kolano, the Loloda people maintained their collective memory of kingship. Like the kolano of the past, the jogugu was considered a sacral being by both Muslim and Christian com- 
munities. ${ }^{6}$ He was believed to have supernatural powers, such as being able to summon rainfall; in addition, he was considered to be protected by alligators believed to be dead kolano ancestors. People were afraid of his curses, which would cause ancestral retribution. Whenever Christian villagers conducted rituals, they would frequently invite the jogugu to pray. Although they did not understand the Islamic prayers, they believed that the prayers had formidable magical powers. In the 196os and 1970s, traditional authorities disappeared from the archipelago due to the anti-feudal policies of the government. The tradition of having a jogugu ended in 1977 with the death of Djamilullah.

After the monetary and political crisis of 1997 and 1998, and following the subsequent period of Reformasi, Indonesia entered a new era characterized by democratization, decentralization, and regional autonomy. These were, however, accompanied by bloody ethnic and religious intercommunal violence from 1999 to the early 20oos, which swept over North Maluku as well. Yet, it was also the time of the rise of identity politics and the comeback of traditional leaders, including the old aristocracies (Van Klinken 2007; Bräuchler 2011). This was part of the reaction of society against the state, which was centralistic and oppressive in nature. During this period, Bayan Malik Syamsudin (an elementary-school supervisor in Loloda subdistrict) was appointed jogugu by Sultan Mudaffar Sjah of Ternate in 1999. Bayan died in 2004, and his cousin, Lufti Syamsudin (a civil servant at the Land Office of the North Halmahera District), was installed as the new jogugu in 2008. When Lufti fell ill, he mandated his position to his brother, Suaib Syamsudin (a policeman working in Ternate), in 2015; Syamsudin was elected as the kolano in 2016.

\section{The Adat Agency and the Contemporary Need to Reinstate the Kolano}

As the prerequisite for a successful adat movement, $\operatorname{Li}(2000: 169)$ identified the 'existence of a local political structure that included individuals (elders, leaders) and an adat council mandated to speak on behalf of the group' and with 'a capacity to present cultural identity and local knowledge in forms intelligible to outsiders'. The adat agency of Loloda was called Lembaga Adat Kerajaan Moloku Loloda (LAKM L, Adat Institute of the Loloda Maluku Kingdom) and was founded in 2008. The adat movements in neighbouring regions often involved political ambitions of individuals, like the case of the district head

6 On the kolano's supernatural power, see also Baarda 1904:325. 
of North Halmahera or that of Mudaffar Sjah of Ternate, whose aims were to emerge as powerful local politicians and win the local elections (see Duncan 20og; Bubandt 2014). Yet, no such political ambition was noticed in the case of Loloda. The seven members of the LAKML included lower-rank civil servants, a university lecturer, and farmers.

The LAKML membership can be categorized into two groups: the descendants of the last kolano and the adat representatives (I. tetua adat) from some autochthonous clans. The kolano group included Lufti Syamsudin (jogugu), Mustafa Mansur, Arsad Sahjuan (farmer), and Puasa Sehe (farmer). The clan leaders included Heres Lalomo, Yonas Toseho, and Yopi Luo, all of whom were farmers.

The adat revival was designed to overcome the cultural crisis and social suffering as well as announce the aspirations of the Loloda people for the future. The LAKML members mentioned the four specific aims they hoped to achieve with the revival. First, the LAKML saw adat as a solution for overcoming their low status and poverty by making an appeal to the national and district governments about their ethnic solidarity. Despite its huge territory and abundant natural resources, including manganese, nickel, gold, and resin, the people felt 'forgotten' by the central and local governments. Highlighting the lack of infrastructure, they claimed they were 'treated as stepchildren (dianaktirikan).' While Tobelo and Morotai in northern Halmahera emerged as regional centres and transportation hubs, Loloda did not even have roads for vehicles and still used the perahu (traditional boat) as the primary mode of transportation. Until recently, there were no qualified high schools, and students had to go to nearby cities, such as Ternate or Manado. Since there is no major industry, agriculture, fisheries, and handicraft-manufacturing are the chief means of subsistence. Due to their marginal status, they were often ridiculed by neighbouring ethnic groups and called by the derivative term Lolbo or Loloda bodoh, meaning 'Loloda the stupid'.

Second, the claim for ownership of the tanah hadat (customary lands) and natural resources, like mines, was another powerful reason cited for reviving adat. During the transition from the colonial era to the New Order period, the customarily held village lands and natural resources were ceded to the state, thus earning profit only for the state. During the Reformasi era, indigenous people claimed their rights, which resulted in the state losing millions of hectares of forest land (Hauser-Schäublin 2013; Bakker and Moniaga 2010). In

7 'Merasa dianaktirikan, warga ingin gabung ke Filipina, NKRI terancam?', jpnn.com, 2-12-2015. https://www.jpnn.com/news/merasa-dianaktirikan-warga-ingin-gabung-ke-filipina-nkri-ter ancam (accessed 6-5-2019). 
Loloda, some disputes over land and mines were reported. For instance, during the time of jogugu Lutfi (2008-2015), a land dispute took place with a mining company called Tambang Biji Besi in the village of Ngajam. At the time, Sultan Mudaffar Sjah of Ternate asked the company to stop exploration of the mine, which was his way of showing his authority to the Loloda residents. This caused controversy among the Loloda people on whether the jogugu should be the adat representative. The local people believed that having an adat representative, who would be regarded as the 'owner' of these lands, would be the key to reclaiming these resources.

Third, the adat revival is related to the search for Loloda's new identity and the desire to establish a new district, called Loloda Pasifik (Pacific Loloda), through a successful administrative restructuring of the regions (pemekaran). The separation of the former kingdom's territories into the two districts of North and West Halmahera was perceived by people as destroying their culture and ethnicity. This issue of creating a new administrative order had been a burning topic on the agenda of the adat revival movements throughout the archipelago, and one which often led to bloody clashes, as shown by the North Maluku communal conflict. ${ }^{8}$ In the current district system, the Loloda people live alongside other ethnic groups, such as the Galela and Tobelo. Although they are geographically, historically, and linguistically close, ethnic rivalries remain. While the Tobelo and Galela people hold important positions in the local governments, the Loloda people continue to be neglected. In 2008, the nearby region of Morotai was successfully redesignated the Kabupaten Kepulauan Morotai (Morotai Island District), which became a matter of envy for the Loloda people, resulting in multiple efforts to achieve pemekaran in Loloda. Among the many issues discussed, the plan for a Galela-Loloda District, which was proposed by the North Halmahera District government, was brought to the national parliament. However, this idea was opposed by a group of activists and university students, who demanded the creation of the Pacific Loloda District to uphold Loloda's integrity. ${ }^{9}$

Lastly, the expectation of the adat was that it would serve as a viable means for a Muslim-Christian reconciliation and social cohesion after the disastrous North Maluku violence, which resulted in thousands of fatalities and hun-

8 The demand of the Makian Muslim immigrants to carve out a new subdistrict in the subdistrict of Kao in North Halmahera led to the religious war in North Maluku (see Wilson 2008; Duncan 2005).

9 'Imaloka tolak pemekaran ров Galda', Brindonews. https://www.brindonews.com/2017/10/ imaloka-tolak-pemekaran-dob-galda.htm (accessed 26-10-2017). Imaloka stands for Ikatan Mahasiswa Loloda Kepulauan (Union of University Students at the Loloda Islands). 
dreds of thousands of refugees (see Wilson 2008; Bräuchler 2009). The conflict occurred in the aftermath of the New Order regime's downfall. Under politically and economically unstable conditions, the interests of various oppressed groups exploded in the form of religious conflicts. The conflict impacted Loloda, although official data on the casualties have not been released. The provincial government promptly evacuated the Muslims who were living in the Christian-dominated areas (Loloda and North Loloda subdistricts) to Ternate, and the Christians in the Muslim-dominant areas (Loloda Islands subdistrict) were moved to Manado and Tobelo for over a year to avoid potential attacks from opposing religious groups. This action reduced the scale of violence compared to the neighbouring regions of Tobelo and Galela. However, hundreds of houses in the Loloda subdistrict were burned down by Christian attackers, and villagers of Jikolamo in the Loloda Islands had to pledge to convert to Islam to the Laskar Jihad (Jihad Troops), a radical Muslim paramilitary group. The village of Dorume was devastated by the Jihad group, but the exact number of victims has not been reported.

The local people, as well as others in Maluku, observed that a weakened adat brought on communal conflict. ${ }^{10}$ People believed that ethnicity may supersede religious differences, and a revival of adat may provide a solution to these religious conflicts. Numerous efforts ensued to bring up notions of inclusion and harmony. Notable examples are the resurrection of the traditional domains, that is, the hoana of Tobelo, the soa of Kao and Galela, and the intra-village alliances ( pela) in Ambon. The adat leaders perceived these traditional terrains as ideal societies where no intercommunal conflicts had ever existed, although this was a strategic claim rather than a historical reality.11

During the conflict and in the process of mitigating animosities, the jogugu Bayan, who had been appointed less than a year earlier, emerged as a figure of peace. While his role was limited, some episodes during the conflict reveal that he was perceived by both Muslims and Christians as the centre point of the ethnic group. When some Christians in Loloda heard that the Loloda Christians residing in Ternate were driven out by the Laskar forces, they asked Bayan to pronounce an order (perintah) that would allow them to go to Ternate and join the Pasukan Kuning (Yellow Troops), the army of the sultan of Ternate, which was fighting the Laskar. Bayan, however, did not allow it, fearing that it would cause more casualties amongst Christians. When the conflict worsened, he visited Ternate and met the then-governor of North Maluku Province, Mr.

10 Davidson and Henley 2007; Duncan 2009; Frost 2004; Müller 2013; Turner 2003.

11 See also Bartels 1977; Bräuchler 2010; Duncan 2009; Frost 2004; Müller 2013; Turner 2003. 
Surasmin, to ask permission for Bayan to keep a ship ready to evacuate the Loloda Muslims to Ternate. When the conflict was finally over, with Bayan's mediation, the two groups signed a mutual agreement to no longer fight, and they installed a statue of a white cockatoo (burung kakatua) in Soa-Sio as a symbol of peace. The jogugu's positive role during the conflict strengthened the public's belief concerning traditional authority's constructive role.

Adat Discourses and Practices of Ternate and Jailolo as the Basis of Loloda's Adat

In the articulation of the adat discourses of Loloda, the role of Mudaffar Sjah of Ternate, who was the 'architect' of the adat discourses, was vital. His remarkable resurrection of adat and of positioning himself as the traditional lord fuelled the revitalization of the nominal kingship in Tidore (1999), Bacan (1999), Jailolo (2003), and Loloda (2016). In 1986, Mudaffar Sjah was elected as the sultan for the loyal support he rendered to Golkar, Soeharto's party, when other feudal elites were still inactive. During Soeharto's rule, Mudaffar Sjah served as a member of the national parliament (Dewan Perwakilan Rakyat), chairman of the North Maluku branch of Golkar, and Regional Representative Council (Dewan Perwakilan Daerah) representing North Maluku (Bubandt 2014:88). By 1999, he emerged as one of the powerful candidates for the governor's elections (2001 and 2007) of the newly created North Maluku Province, but it ended unsuccessfully due to his disastrous involvement in the North Maluku conflict (Bubandt 2014:83-5; Wilson 2008:45-8, 74-8).

Mudaffar Sjah tried to build his personal charisma and political standing on the basis of traditional authority generated through the re-operation of adat. From the 1980s, he had begun a vociferous effort to revive the forgotten history and adat of Ternate by taking history courses at the National University of Indonesia (Universitas Indonesia) (Kartomi 1993:189). His adat discourses are articulated in two interwoven discourse strands, the first of which is the mythic rhetoric of the Kie Raha, and the second comprises republican ideas identifying the sultanates as modern and democratic institutions.

The discourse of the unity of Kie Raha was meant to restore traditional notions of the socio-cosmological order of the Maluku World, through which he reanimated his traditional sovereign claim as the lord of Ternate and the overlord of the former dependencies in Halmahera, thereby uniting the heterogeneous population of North Maluku under his patronage. Although he only had partial control, since the Indonesian Republic constituted a higher level of political order, he enjoyed dynamic, symbolic power in the popular ima- 
gination. The discourse of the Kie Raha had been popular among the North Maluku people for a long time. They saw that the power balance of the four central states and the unity of Maluku was essential for regional prosperity. Multiple-origin myths emphasizing the common ancestral belonging revealed the long existence of such notions in the collective identity (Andaya 1993a:256). Amongst them, Mudaffar Sjah claimed to be the descendant of Jafar Sadek, an Arab merchant-cum-sayyid ${ }^{12}$ and a heavenly nymph named Nursafa (Song 2020; Bubandt 2014:96-7). According to the myth, their four sons became the founder kings of the Kie Raha, while their four daughters married the kings of Loloda, Banggai, Tobungku, and Marsaoli-Mardike, respectively (M. Rahman 2006:2-3). The other Kie Raha courts of Tidore, Bacan, and Jailolo also adopted this rendition as their royal-origin myth (Song 2020).

Subsequently, the loss of Jailolo in 1551 due to its subjugation to the TernatePortuguese alliance was indicative of an 'incomplete and unbalanced world' (Bubandt 2014:106) and the cause of misfortunes, including colonial rule. Multiple revitalization efforts were undertaken by Prince Nuku of Tidore (17801810) and Dano Baba Hasan of Ternate (1876). ${ }^{13}$ In the contemporary period, the Kie Raha discourse re-emerged after the 1950s, when the region was integrated into the Maluku Province with Ambon as its capital, which was perceived as their historical periphery. The Kie Raha rhetoric was strengthened when the North Maluku people demanded the pemekaran of a new province, which was finally achieved with the formation of the North Maluku Province in 1999. Mudaffar Sjah also emphasized this discourse to secure his personal ambition to be the first democratically elected governor of the new province. To secure the loyalty of the northern Halmahera population, he reinstated the sultan of Jailolo (2003) and the jogugu of Loloda (1999) to gain public support by calling on his traditional role as the overlord.

Nevertheless, Mudaffar Sjah also emphasized that his traditional sultanates were modern, democratic institutions, which coexisted within the republic order, and thus provided a counter discourse to groups opposing the resurrection of the hereditary elites (Bräuchler 2011:203). Bubandt (2014:91-2) quotes from his interview with Mudaffar Sjah on his claim:

I know that the sultanate tradition is very democratic, because I wrote my thesis on the traditions and philosophy of North Maluku (T. Moloko Kie raha) using the philosopher ... what's his name ... Adam Smith ... and his

12 Sayyid means a Muslim who claims to be a descendant of the prophet Muhammad.

13 Andaya 1993b:214-39; De Clercq 1999:69-71; Mansur and Said 2018; Widjojo 2009. 
thoughts on freedom. But, when you think about it, what is democracy, really? It is, of course, an institution from the West; an institution that in its current form is not appropriate (I. cocok) with life here. In actual fact, however, the traditional sultanate system that existed here in former times was already very democratic, tolerant and free. Democracy originally came from here, from the sultanates of North Maluku!

Mudaffar Sjah installed various adat offices that 'foreshadowed their modern political equivalents' and were 'complete with ministers, parliamentary members, deliberative chambers and civil-society representatives' (Bubandt 2014:83). In the court structure, the sultan was equivalent to the head of state of a republic; jogugu, to the prime minister; and kapita (war leader), to the minister of defence. The court structure also assumed the separation of power between the executive (sultan) and the legislative branches (an adat council called the Bobato 18). In theory, the sultan was to be elected by the Bobato 18, although this rule was not well kept in the Ternate court (see Song 2020:12930). The articulated identity of the king as the traditional ruler and the democratically appointed one was copied by other kingships in Tidore, Bacan, Jailolo, and Loloda.

Yet, overall, Mudaffar Sjah's adat revival was not entirely successful. While he emerged as a powerful authority in Ternate and parts of northern Halmahera, he failed to gain legitimacy from all segments of the population, particularly after his involvement in the North Maluku conflict. When a small conflict between the Kao Christians and the Muslim Makians developed into a religious war, Mudaffar Sjah tried to protect the former, because he positioned himself as the overlord of the Kao people as well (Jäger 2018:156; Wilson 2008). This led to Muslim anger against him, loss of popularity, and a weakening of his position as the adat leader in Ternate.

Moreover, the revived Jailolo kingship generated heated arguments both for and against the kingship due to the lack of legitimacy of the sultan (Mansur and Said 2018:146). As the royal descendants were no longer traceable, Mudaffar Sjah found a man named Abdullah Harianto (later Abdullah Sjah), a retired army officer from Java, through his so-called magic power and claimed that he was the rightful incarnation of Katarabumi (1534-1551), the last sultan of Jailolo (Bubandt 2014:106-7; Jäger 2018:138-41). However, questions regarding his genealogical connection to Katarabumi and his appointment by the sultan of Ternate threatened his position.

More importantly, the nomination of Abdullah Sjah by Mudaffar Sjah did not gain the approval of the autochthonous leaders, whose authority as the lords of the land (tuan tanah in Malay) was still considered vital for the adat 
revival in regions where the stranger-kingship formula was practised. As many scholars have noticed, origin narratives are historical sources in which the hierarchical relations of communities are encoded. ${ }^{14}$ In particular, the strangerkingship myths generally narrate how the autochthons transferred political power to 'sacral strangers'. The foreigners built relationships with the indigenous population through marriage to autochthonous women, who represented territorial and kinship units and ancestors. In many regions where this myth exists, the two groups have been known to develop reciprocal rights and duties based on social contracts and create a diarchy. In this dual leadership system, the autochthonous leaders held the authority of being ritual overseers or spiritual leaders, while the foreign groups held political office and were responsible for warfare and public order (Baker 1988:15). Indeed, in the pre-modern Kie Raha states, a diarchical social order is observed (Andaya 1993b; Platenkamp 2013:207-10; Widjojo 2009:47-52). In Ternate and Tidore, for example, Andaya (1993b:174-5) points out that the autochthonous leaders acted as the principal functionaries at the court, which was collectively called the bobato. In Ternate, the head of the bobato was the jogugu, while in Tidore, it was the jojau; both terms can be translated as the 'lords of the land'. Being members of the adat council, which was in charge of electing and dismissing foreign sultans, they provided rulers with checks and balances for their power. Despite their vital roles, they were commoners, and the aristocracy referred only to the descendants of Jafar Sadek and Nursafa.

In fact, since the kingdom's collapse, Jailolo's original population has migrated to other regions, and the majority today are Muslim migrants from Sula and Tobaru in northern Halmahera and Ternate (Jäger 2018:151). Yet, some adat leaders from the four earliest villages are still known as the lords of the land, forming the legislative body called tau raha. However, only two adat elders from the villages of Gamlamo and Moro were nominated by Mudaffar Sjah, while the ones from Porniti and Wayoli did not recognize Abdullah Sjah as the rightful sultan (Jäger 2018:142-9).

Unwillingness to acknowledge Abdullah Sjah was also seen among the Christian population, especially in the Sahu and Tobaru regions. They pledged their loyalties to the Ternate sultan as their overlord, but perceived Abdullah Sjah as the representative of the Muslim population only (Jäger 2018:150-7) In rejecting the sultan, they developed a well-known ethnohistorical discourse, which asserts that the last sultan of Jailolo did not die but vanished into the spirit world and became a makhluk halus (invisible being). Accordingly, he can-

14 Cummings 2002; Gibson 2005; Fox 2008; Fox and Sather 2006; Kaartinen 2019; Lewis 1988. 
not return to the human sphere (Jäger 2018:153-4). When relations between Mudaffar Sjah and Abdullah Sjah were strained over their support of different political parties and candidates in the 2010 district head election, resulting in the former's 'dismissal' of the latter as the sultan, these Christians supported Mudaffar Sjah (Jäger 2018:156-7; Bubandt 2014:108-9). Thus, the kingship of the Jailolo failed to accommodate the entire population because the Christians apparently felt excluded from this sultan-based adat representation. While Abdullah Sjah still managed to retain the title of sultan without the support of Mudaffar Sjah, three other persons claiming to be the legitimate sultan during the years 2002-2017 received support from different groups of the population (Mansur and Said 2018:137).

The Jailolo case illustrates the weakness of the adat movements, particularly the ones based on kingship, which were to encompass huge areas, thus intrinsically posing the issue of exclusion of certain groups from its representation. Hall (1996:5) quoted Bhabha (1994) on the matter of exclusion saying that the 'unities' that the identities proclaim are 'in fact, constructed within the play of power and exclusion, and are the result, not of a natural and inevitable or primordial totality but of the naturalized, overdetermined process of "closure". Since the adat movements represent claims for indigenous rights by nature, the migrants are the ones mostly excluded from the adat movement. Yet, the case of Jailolo reveals that the nomination of the sultan was seen as the exclusion of the Christian population.

Adat Discourses of Loloda and the Themes of Centrality, Sovereignty, and Intragroup Relations

As briefly mentioned earlier, Mudaffar Sjah visited Loloda with a few Golkar members to install Jogugu Bayan in 1999. Whether it was intentional or not, by establishing the jogugu, Mudaffar Sjah provided the Loloda people with the centripetal force to promote and articulate their adat and identity. The forging of new identities for Loloda entailed two dimensions of claims. First, Loloda is one of the centres of Maluku; it is not on the periphery. Second, the revived Muslim kolano is the lord of all people, both Christians and Muslims.

As in the case of Jailolo, the discourse of the Kie Raha became the frame of reference; however, the LAKML rearticulated the myth and said that there were five centres, and therefore the alliance should be called the Kie Romtoha (Five Mountains). The Kie Romtoha formula was found in the famous narrative on the Moti Conference in 1322, which was held on the island of Moti. According to the oral narrative transcribed by Van der Crab, a Dutch resident of Ternate, 
it was a historic event wherein the Kie Raha alliance was created with the consensus of the four kolano from the Kie Raha courts (Naidah 1878:39o). As per the myth, the kolano of Loloda was also invited, but he arrived late because of strong winds. His tardiness resulted in the exclusion of Loloda from the Kie Raha composition. The Loloda people, however, suspected that the exclusion was a deliberate act by the other kolano because Loloda was the oldest kingdom, which meant that it was hierarchically superior. Despite Loloda's exclusion, the LAKML activists claimed that the kolano's presence at the conference proved the kingdom's central position.

The LAKML activists also used the seventeenth-century epithet of Robertus Padtbrugge (1677-1682), the Governor of the Dutch East India Company in Maluku, to infer their centrality. Padtbrugge noted that there were five central kingdoms in Maluku, which were 'Loloda, Ngara ma-beno' (Wall of the Gate), 'Jailolo, Jiko ma-kolano' (Ruler of the Bay), 'Tidore, Kië ma-kolano' (Ruler of the Mountain), 'Ternate, Kolano ma-luku' (Ruler of Maluku), and 'Bacan, Kolano ma-dehe' (Ruler of the Far End) (Andaya 1993b:51). Andaya (1993b:52-3) doubts the legitimacy of Loloda's inclusion because although there was a kolano during this period, his kingdom had already disappeared. Therefore, he deduces that its inclusion was due to its geographical location, which represented the North and complemented Maluku's cosmogony that connected the Upper (Loloda), Middle (Ternate, Tidore, Jailolo), and Lower (Bacan) Worlds.

Yet, the articulation of centrality as the legitimate past simultaneously meant the de-articulation of Loloda's modern history under Ternate's suzerainty. In other words, it was a rejection of the semi-sovereign claim of Mudaffar Sjah over Loloda. These historical relations between Loloda and Ternate became an issue when the LAKML activists schemed to reinstate the kolano. The vital question they faced was, who would authorize the kolano? Although Mudaffar Sjah was alive when they began considering reinstating the kolano, they felt it would be absurd if he was the one to appoint the kolano (even though the jogugu was instated by him), because this would then recognize the Ternate sultan as being a higher authority than, and an overlord to, their kolano. They were reminded of the lack of legitimacy of the Jailolo sultan, who had been chosen by Mudaffar Sjah. This had left the impression with the population that the sultan was not an autonomous ruler; thus the removal of Mudaffar Sjah's sovereign influence was vital.

Rather than depending on any external source for sovereignty, the LAKML activists used the royal-origin myth and called on traditional perceptions of sovereignty based on the diarchy. Despite being historically marginalized, Loloda retained 'a special place in Maluku ceremonies' because of its link to some of the famous myths (Andaya 1993b:93). One was the origin narrative of Bacan, 
transcribed in the sixteenth century. It narrates that an elder, Bikusigara of Bacan, found four naga (serpent deity) eggs, out of which three men and one woman were born. Eventually, the three men became the kings of Bacan, Papua, and Butung-Banggai, while the woman became the wife of the king of Loloda (Jacobs 1970:81). A different version of the Bacan myth, transcribed by W.Ph. Coolhaas (1923:502-5), a Dutch colonial officer and historian, narrates that the founder king of Loloda was connected to Jafar Sadek. Jafar had one daughter and four sons: the oldest son became the first king of Bacan; the other three became the kings of Jailolo, Tidore, and Ternate; and the daughter lived in Banggai. The Bacan king gave birth to five sons and two daughters. After he died, a catastrophic flood swept the region, carrying away his six children, all of whom disappeared, except his first-born son. While the first son inherited the kingship in Bacan, the other children appeared at islands like Loloda, Papua, and Banggai and became kings.

Currently, however, the oral myth adopted by the LAKML regarding kingship is the Jou Tolo myth, which is a variant of the Jafar Sadek and Nursafa myth. The use of this myth indicates that the origin myth once articulated by Mudaffar Sjah, which was the basis of the Kie Raha, was re-articulated as the basis of the Kie Romtoha. The Jou Tolo myth is as follows:

Jou Tolo (Kolano Usman Malamo) was the brother of Nursafa, the heavenly nymph. Tolo descended to Earth to find his missing sister, who was by then married to Jafar Sadek. Jou Tolo first settled in Galela, but after the eruption of the volcano, he fled to Loloda hidden in the volcano smoke. He dwelt in Galela and Loloda because of his conflicts with Jafar in Ternate. When he first arrived in Loloda, he transformed himself into a white cockatoo and sat on a coconut tree. Underneath the tree was a small pond called the Ake Kolano (king's water, also called the Ake Kaca or the Mirror Water). A village man from Laba was passing by the pond when his dog began to bark. The man looked at the pond and saw the shadow of a human sitting on the tree. He ran from the site and went back to the villages of Laba and Bakun to inform the people. The villagers came to the pond and asked the white bird to reveal his true identity. The white bird transformed itself into a human. The leader of the villages was Bakun Malamo, who then ceded some land near his village to Jou Tolo. Jou Tolo married Bakun Malamo's daughter, whose descendants became the noble group..$^{15}$

15 Transcribed by the authors. The villages of Laba and Bakun are located near the old settlement of Soa-Sio. 
In Loloda, Jou Tolo was known as the bringer of Islam. His identity as a heavenly nymph who was Muslim illustrates the syncretic nature of Islam in the region. Genealogically, Jou Tolo's ties as the brother of Nursafa and affine of Jafar indicates that Loloda shares ancestry with the Kie Raha, thereby confirming Loloda's centrality. Jäger (2018:48-9) also argues that Jou Tolo being the older brother of Nursafa indicated Loloda's seniority in the Kie Raha states.

The Jou Tolo narrative is also a stranger-kingship myth, as it narrates how a sacred outsider was made a king by the autochthons. This relationship between the king and the autochthons was articulated by the LAKML to aid MuslimChristian reconciliation. As mentioned earlier, Jailolo's failure to include the Christian population into the revived adat was a grave matter, because Loloda was also divided in terms of religion. The LAKML activists then articulated the diarchic elements embedded in the myth to ensure that the two groups participated equally in the revived adat discourses and practices, and eventually turned it into a platform to accommodate both groups within the frames of ethnicity.

In Loloda, few records indicate that diarchic relations between the rulers and the people were at play, despite some titles indicating that the lords of the land were sustained, like jogugu and sowohi (a ritual specialist). Unlike Ternate or Tidore, where jogugu (or jojau) represented the autochthonous population and belonged to the commoners, the jogugu of Loloda was elected from the noble group, and the election of the kolano was not made through the adat council but through a court ritual during which the ancestral spirits were thought to elect the kolano. Still, the activists observed that the diarchic elements between Jou Tolo and the autochthonous leaders from Laba and Bakun could be utilized. These two villages, along with the Kedi and Tobaru, are known as the four earliest settlements of Loloda. The adat elders of these villages are still esteemed by the local people as the 'original settlers'.

Specifically, Bakun Malamo is revered as the apical ancestor of Loloda. In the myth, Bakun symbolizes the stranger's construction of an affine and political bond with the indigenous land as well as oppositional authority against the outsider. As the earliest settlers, the Bakun clan may have claimed the right to control the rituals and the land. The narrative reflects this when it states that Bakun gave Jou Tolo some land near his village, which became the old settlement of Soa-Sio. His original village and street, for example, are named after Bakun Malamo (Figure 2). Their descendants still claim customary rights to be the adat elders of the Bakun village and, currently, Heres Lalomo holds the title of the Bakun Malamo. Hence, the LAKML members articulated the mythic narrative concerning the power transfer from the autochthons to Jou Tolo. The 


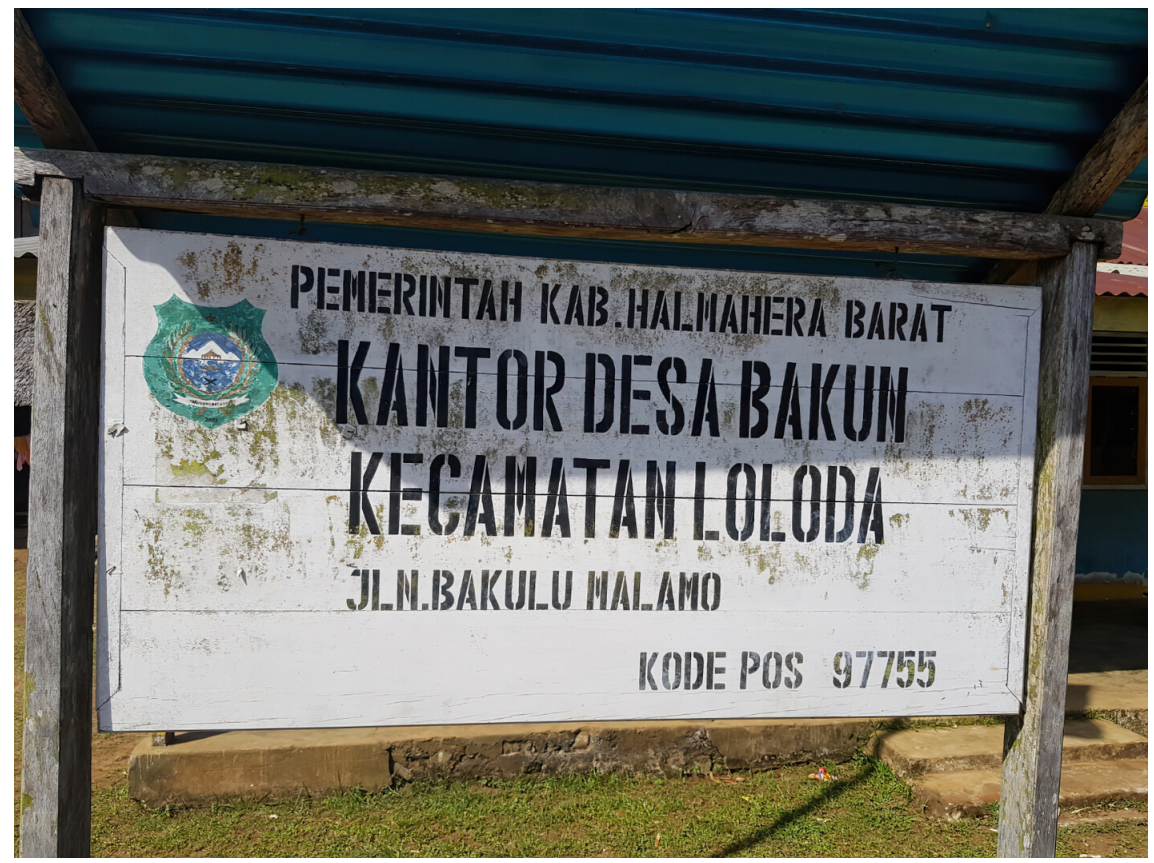

FIGURE 2 The sign board of the Bakun Village and the Bakulu Malamo Street (C)AUTHORS, 2019

activists asked the four leaders of the earliest villages to be the representatives of the 'people' and to 'authorize' the new kolano, although the selection of the kolano (from a pool of multiple candidates) was done by the royal families. Therefore, it was not only the kolano but also the titles of the 'lords of the land' that were officially revived.

Calling on the diarchy was also useful for promoting intragroup relations, which, the activists believed, had been ruined by external influences throughout history. Indeed, Ternate's overlord system and Christianization brought about a new perception of sovereignty and authority in Loloda. As the sultans of Ternate emerged as the new authority figures for both Muslims and Christians in the dependencies overseas, they also began to generate divisiveness between the Muslim and alifuru communities by calling Muslims 'the children of the village' (ngofa gamu), while the alifuru were the 'people of the land' (mancia halefuru; Platenkamp 2013:211). With the Christianization of the alifuru population, religious polarization had become increasingly pronounced, which led to different perspectives in viewing the alifuru and the Muslims. Previously, their division had been based on the precedence order of arrival, with the autochthons (the alifuru) arriving first, followed by the immigrant group. 
The LAKML activists saw that the division of society along religious lines had paved the way for the faith-based conflicts in the contemporary era. By reviving the diarchy, to borrow Platenkamp's (2013:206) expression, the activists were attempting to revert the modern notion of sovereignty that was based on 'religiously grounded claims at universal sovereignty', which had been imposed by the sultans of Ternate, to the traditional idea based on 'cosmologically authorized models of sovereignty'.

The endowment of power to mandate the new kolano for the villagers was not based on religiosity but on their status as the 'lords of the land'. To reiterate, the kolano families were Muslims, while the autochthonous villagers were Christians; hence, the revival of a diarchy was brilliant because it provided a platform for religious harmony. The adat activists intentionally accorded the important role of instating the Muslim kolano to the Christian villagers, as they anticipated he would be the centripetal point for the Loloda people, regardless of their religious differences. In addition, unlike other Kie Raha courts, the word kolano was strategically used instead of sultan, because the LAKML activists were concerned that the term 'sultan' would give the impression that he was the lord of the Muslim communities only. The LAKML members emphasized that by calling the king kolano, it would be clear to all that he would be the king of all, including Muslim and Christian communities.

The use of the diarchic element was also useful in describing their kingship as democratic. As Platenkamp noted, the diarchy was intrinsically democratic as it constituted '[the] ideal modality of the mutual obligations and rights, pertaining to the relations between the ruler and the people' (Platenkamp 2013:207). The LAKML activists emphasized that the power of the kolano was given to him by the people, and they designed the rituals carefully to embody this perception, as will be seen in the next section.

In 2016, two rituals were held, the first of which was called the Ritual Adat Kolano Madadhi (L., Adat Ritual for Instating the Kolano). Beginning on 1o March, the ritual was held for nine days in the new settlement of Soa-Sio, where the Christian population is dominant. This is an established annual ritual that had previously been held to recall the collective memories of Jou Tolo and offer prayers to God for protecting the people and providing a bountiful harvest. By the 1970s, it was held infrequently and then entirely halted from the 1980s to the 1990s. Eventually, the ritual was held again in 1999, 2010, and 2016, motivated by kolano families' personal desire to request that royal ancest- 
ors blessed them, but the latter year was special because it entailed the election of a new kolano.

The ritual followed the performance of a salaijin, which is a mystical dance widely known throughout North Maluku. Some of the people become possessed by spirits while dancing, and they communicate with their dead ancestors (or jin) and ask for help concerning the various problems they face. The people authorized to participate in the ritual are confined to the noble group's circle, while Christians are not allowed to participate or even visit the location of the ritual. Once, some Christians approached the place, and the noblewomen stopped dancing to warn them that their 'smell' was negatively affecting the ritual. During the salai jin, smoke from the incense fire enhanced the magical aura as a dozen men and women danced in a possessed state. Some women danced like heavenly nymphs or alligators, while several kolano candidates, all of whom were the descendants of the last king, sat and watched. On the final day, a noblewoman became possessed by the spirit of Jou Tolo, and she pointed towards Suaib Syamsudin to pay him respect.

On 10 December, another ritual was held, called Sigoraka de Sinonako Kolano (L. Authorize and Acknowledge the Kolano). In the ritual, the adat elders from the earliest villages (namely, Heres Lalomo from Bakun; Yopi Luwo, Yonas Toseho, and Yonatan Tuka from Kedi; and Titus Moraka from Tobaru) participated as the party that mandated (mendaulat) the new kolano. An elder from Laba was also invited, but he fell ill and hence did not participate. This ritual was the embodiment of the mythic narratives involving the autochthons giving political authority to the stranger-king. The peak of the ritual was the crowning of the new kolano, which was conducted by Bakun Malamo, who placed the king's hat (peci raja) on the kolano's head. Afterwards, Yopi read the script (wejangan), which was reminiscent of the social contract that had been established between Jou Tolo and the autochthons. Read in the Loloda language, the wejangan indicated the status of Loloda as one of the five central states and discussed the relationship between the kolano and his people:

On this day, Saturday, 10 December 2016, we, the people of your highness, declare you as our lord (tuan raja). We would like you to know these things: the king of Moloku Loloda is the Ruler as well as the Gate Keeper (of the North); Jailolo is the Ruler of the Bay (maritime); Bacan is the Ruler of the Far End (South); Tidore is the Ruler of the Mountain (mainland); and finally, Ternate is the Ruler of the Maluku. You may walk on the king's bridge because you are the incarnation of all the [ancestor] kings. The full moon, bordered by shining gems and gold, will surround you. Your mountain is named, Tolimadu; your water is called the Mirror Water; your 
garden is laid with gold; and your bay is beautiful. I bow my head down in supplication to you and raise my head to worship and greet you, our lord King. ${ }^{16}$

The white cockatoo that Jou Tolo transformed into in the myth was made the state symbol. The body of water along the beach where Jou Tolo was first discovered is now revered as a sacral place for remembering the kolano. While the location usually contains salt water, when the royal ritual is being conducted, the water mysteriously transforms into fresh water. People drink this water as they believe it has medicinal benefits. The community has now devised a plan to revive the kedaton (royal palace), which was earlier in the historical Soa-Sio location.

Right after the inauguration, in December 2019, Kolano Syamsudin instated the major adat offices, including jogugu, kapita lau (navy commander), kapita kie (army commander), Jo hokum (judge), and bobato dunia dan akhirat (the bobato of the world and afterlife). He also visited 11 villages in the Loloda subdistrict and two villages in the Loloda Islands subdistrict and instated adat officers, like the mahimo (village judge), fanyira (the head of soa), and kapita. Similar adat offices were installed in seven villages in Central Loloda subdistrict in November 2020, while the plans for the North Loloda subdistrict have been postponed due to the COVID-19 pandemic. These actions were to gain public recognition for the kolano as their adat representative and to consolidate the population under his symbolic authority. Ever since the kolano's installation, he has participated in events held by various organizations with sultans and rajas of the archipelago, such as the Forum Silaturrahmi Keraton Nusantara (Friendship Forum of the Palaces of the Archipelago) and the Festival Keraton dan Masyarakat Adat (Festival of Palaces and Indigenous People).

Unlike Jailolo, public acceptance of the kolano as their adat leader is noteworthy. While Abdullah Sjah's royal genealogy roused public suspicion, neither Jogugu Lutfi nor Kolano Syamsudin faced such a problem.Jäger (2018:150) notes that, when she visited Loloda in 2012, the local raja (indicating Jogugu Lutfi) enjoyed a high level of public acceptance. This is because the last kolano was deposed only in the early twentieth century, and people still recognize those belonging to the royal family.

In addition, the people of Jailolo who did not want to recognize the sultan as their adat representative established competing adat organizations, that is, village adat councils or organizations affiliated to the Aliansi Masyarakat

16 Translated by the authors. 


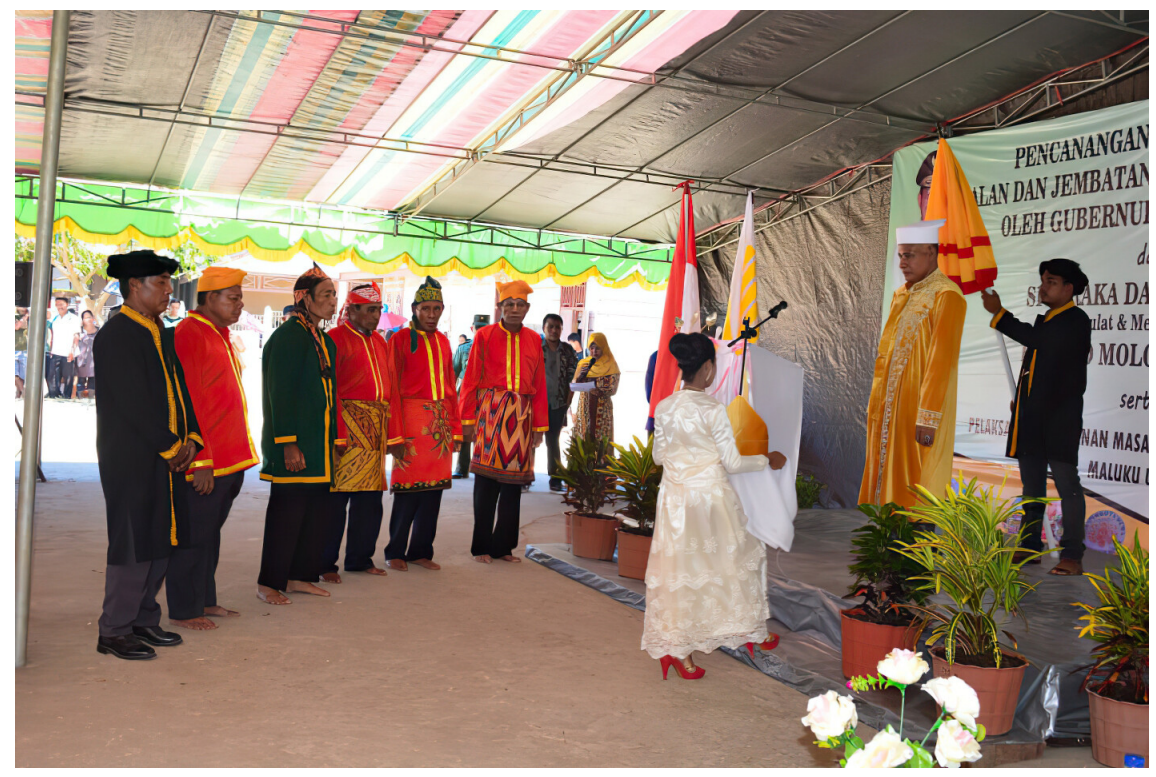

FIGURE 3 The kolano in gold attire and the 'lords of the land' in red attire (C)AUTHORS, 2016

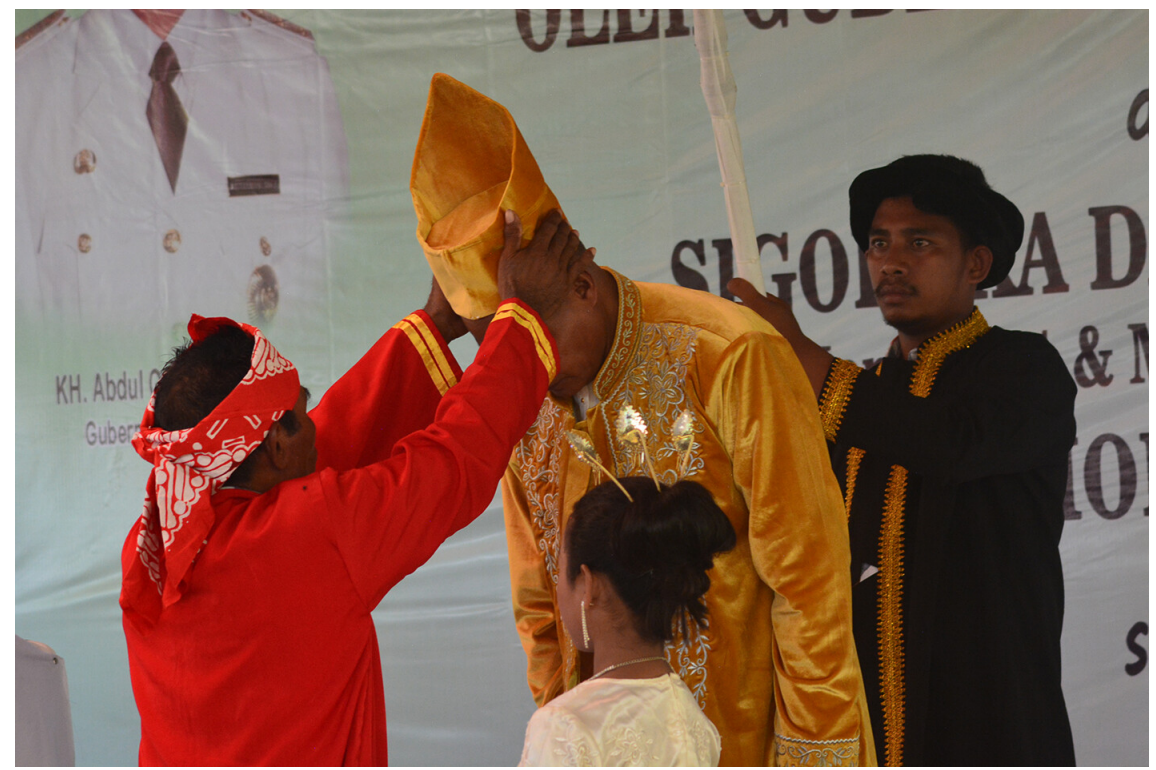

FIGURE 4 Heres Lalomo (Bakun Malamo) crowns the kolano, Suaib Syamsudin (C)AUTHORS, 2016 
Adat Nusantara (AMAN, Indigenous Peoples Alliance of the Archipelago) (Jäger 2018:190-1). AMAN is the umbrella organization of indigenous peoples, and it usually rejects the articulation of the kingship as the adat representation while emphasizing the importance of grass-roots adat movements. Yet, no such counter efforts have been observed in Loloda so far.

This does not indicate, however, that Loloda's kingship has been designed to accommodate the entire population, including the migrants. Mudaffar Sjah had earlier appointed a Chinese businessman as the kapita Cina (Chinese war leader), an act presumably to incorporate the non-indigenous population into the adat structure. Jogugu Bayan once appointed a Chinese named Hendrik Basare as the kapita Cina of Loloda, yet after his death, the position has not been filled yet. The LAKML is aware of this matter of exclusion and has devised a plan to reinstate the kapita Cina in the near future.

Despite these limitations, the new kolano certainly appears to represent the Loloda people as their adat representative. Since no alternative adat institutes are operational, the local people have asked the kolano to represent their interests in various issues. For instance, in 2019, they resisted the opening of mines by Рт. тUв in the Loloda subdistrict and asked the kolano to be their delegate in voicing their interests. Initially, the company invited a few AMAN figures from North Halmahera and a Ternate prince to be the delegates of the adat group. However, the Loloda people refused and said that they already had a kolano. Without his presence at the negotiation, they claimed that any discussion would be illegitimate. ${ }^{17}$

This article explored the broader socio-political backdrop against which the reinstatement of the kolano in Loloda took place. In addition, it looked at how a marginalized group articulated their fragmented historical and mythic narratives to renegotiate their status to a central position, while facilitating religious reconciliation. It also examined how adat discourses and rituals, symbols, and narratives were mobilized to enable the local people to shift their locus of identification from religious to ethnic identity.

The Loloda case shows how adat activists reanimated traditional notions embedded in the myths and articulated them to create a cultural basis for the

17 This dispute continues. Рт. тив has suggested holding an official meeting with the kolano in Jakarta, and the kolano is preparing for a public consultation on this matter before he meets with the company. 
revived kingship. The LAKML activists successfully articulated the Kie Romtoha myth to promote the region as one of the five mythic centres of Maluku. They also articulated diarchic elements that were established between their Muslim stranger-king ancestor and the alifuru (later Christianized) population to facilitate reconciliation between the two religious groups. This perception of diarchy was articulated as a democratic tradition, which was necessary for the legitimacy of resurrecting the feudal leadership in the contemporary era.

The Loloda case illustrates that the North Maluku people's traditional cosmological perception of the Upper, Middle, and Lower Worlds, as well as the centres and peripheries, and the concept of sovereignty were called on to formulate the adat revival discourse. This revival of tradition was, as Bräuchler (2010:66) argues, 'less a desire to return to a mystic and seemingly glorious past with all its consequences, than a future-oriented move with various motives, whether to resolve the Moluccan conflict or for political or economic advantage'. Thus, it was not only a cultural act but also a political one, with detailed strategic aims to secure better positions in the local context. The Loloda case contributes to a better understanding of the various ways in which histories and culture are articulated in Indonesia, and it demonstrates the relevance of the mythic narratives in contemporary lives.

\section{Acknowledgements}

This research was supported by the Hankuk University of Foreign Studies Research Grant of 2020. The authors would like to thank two anonymous reviewers, as well as Sony Karsono, Muhammad Sabri, and Budy Anfield, for their perceptive comments on, and suggestions for, this article. All shortcomings are ours.

\section{References}

Abdullah, T. (1966). 'Adat and Islam: An examination of conflict in Minangkabau', Indonesia and the Malay World 2:1-24.

Andaya, L.Y. (1993a). 'Cultural state formation in eastern Indonesia', in: A. Reid (ed.), Southeast Asia in the early modern era:Trade, power, and belief, pp. 23-41. Ithaca, NY: Cornell University Press.

Andaya, L.Y. (1993b). The world of Maluku:Eastern Indonesia in the early modern period. Honolulu: University of Hawai'i Press. 
Baarda, M.J. van (1904). 'Het Lòda'sch, in vergelijking met het Galèla'sch dialect op Halmaheira', Bijdragen tot de Taal-, Land-en Volkenkunde van Nederlandsch-Indië $5^{6-}$ 3/4:317-496.

Baker, J.N. (1988). Descent and community in Tidore. [PhD thesis, University of Michigan.]

Bakker, L. and S. Moniaga (2010). 'The space between: Land claims and the law in Indonesia', Asian Journal of Social Science 38-2:187-203.

Bartels, D. (1977). Guarding the invisible mountain: Intervillage alliances, religious syncretism and ethnic identity among Ambonese Christians and Moslems in the Moluccas. [PhD thesis, Cornell University, Ithaca.]

Bhabha, H. (1994). The location of culture. London and New York: Routledge.

в Ps Kabupaten Halmahera. Loloda dalam angka 2017. Loloda: BPS Kabupaten Halmahera Barat.

Bräuchler, B. (ed.) (2009). Reconciling Indonesia: Grassroots agency for peace. London: Routledge.

Bräuchler, B. (2010). 'Integration and exclusion: Islam adat in Central Moluccas', Indonesia and the Malay World 38-110:65-93.

Bräuchler, B. (2011). 'Kings on stage: Local leadership in the post-Suharto Moluccas', Asian Journal of Social Science 39-2:196-218.

Bubandt, N. (2014). Democracy, corruption and the politics of spirits in contemporary Indonesia. London: Routledge.

Clercq, F.S.A. de (1999). Ternate: The residency and its sultanate. Washington, DC: Smithsonian Institution Libraries Digital Edition. [First published in 1890 as Bijdragen tot de kennis der Resident Ternate. Leiden: Brill.]

Clifford, J. (2001). 'Indigenous articulations', The Contemporary Pacific 13-2:467-90.

Coolhaas, W.Ph. (1923). 'Kroniek van het rijk Batjan', Tijdschrift voor Indische Taal-, Land- en Volkenkunde 63:474-512.

Cummings, W. (2002). Making blood white: Historical transformations in early modern Makassar. Honolulu: University of Hawai'i Press.

Davidson, J.S. and D. Henley (eds) (2007). The revival of tradition in Indonesian politics: The deployment of adat from colonialism to indigenism. London: Routledge. [Contemporary Southeast Asia Series.]

Duncan, C.R. (2005). 'The other Maluku: Chronologies of conflict in North Maluku', Indonesia $80: 53^{-80}$.

Duncan, C.R. (2009). 'Reconciliation and revitalization: The resurgence of tradition in postconflict Tobelo, North Maluku, Eastern Indonesia', The Journal of Asian Studies 68-4:1077-104.

Fox, J.J. (2008). 'Installing the "outsider" inside: The exploration of an epistemic Austronesian cultural theme and its social significance', Indonesia and the Malay World 36-105:201-18. 
Fox, J.J. and C. Sather (eds) (2006). Origins, ancestry and alliance: Explorations in Austronesian ethnography. Canberra: Australian National University Press.

Frost, N. (2004). 'Adat in Maluku: New value or old exclusions?', Antropologi Indonesia 28:1-10.

Gibson, T. (2005). And the sun pursued the moon: Symbolic knowledge and traditional authority among the Makassar. Honolulu: University of Hawai'i Press.

Grossberg, L. (1996). 'On postmodernism and articulation: An interview with Stuart Hall', in: David Morley and Kuan-Hsing Chen (eds), Stuart Hall: Critical dialogues in cultural studies, pp.131-15o. London: Routledge.

Hall, S. (1986). 'On postmodernism and articulation: An interview with Stuart Hall', Journal of Communication Inquiry 10-2:45-6o.

Hall, S. (1996). 'Who needs identity', Questions of Cultural Identity 16-2:1-17.

Hauser-Schäublin, B. (ed.) (2013). Adat and indigeneity in Indonesia: Culture and entitlements between heteronomy and self-ascription. Göttingen: Universitätsverlag Göttingen.

Henley, D. (2002). Jealousy and justice: The indigenous roots of colonial rule in northern Sulawesi. Amsterdam:vu Uitgeverij.

Henley, D. and J.S. Davidson (2008). 'In the name of adat: Regional perspectives on reform, tradition, and democracy in Indonesia', Modern Asian Studies 42-4:815-52.

Hobsbawm, E. (1983). 'Introduction: Inventing traditions', in: E. Hobsbawm and T. Ranger, (eds), The invention of tradition, pp. 1-14. Cambridge: University of Cambridge.

Jacobs, H. (ed. and transl.) (1970). A treatise on the Moluccas (c. 1544), probably the preliminaryversion of António Gãlvao’s lost História das Molucas. Rome:Jesuit Historical Institute.

Jäger, K. (2018). Das Sultanat Jailolo: Die Revitalisierung von 'traditionellen' politischen Gemeinwesen in Indonesien. Berlin: Lıт Verlag Münster.

Kaartinen, T. (2019). 'Islamic transformations in the periphery of Maluku, Indonesia', Indonesia and the Malay World 47-138:184-98.

Kartomi, M.J. (1993). 'Revival of feudal music, dance, and ritual in the former "spice islands" of Ternate and Tidore', in:V.M. Hooker (ed.), Culture and society in New Order Indonesia, pp. 185-210. Oxford: Oxford University Press.

Klinken, G. van (2007). 'Return of the sultans: The communitarian turn in local politics', in: S.D. Jamie and H. David (eds), The revival of tradition in Indonesian politics: The deployment of adat from colonialism to indigenism, pp. 149-165. New York: Routledge.

Lewis, E.D. (1988). People of the source. Dordrecht: Foris. [KITLV Verhandelingen.]

Li, T.M. (2000). 'Articulating indigenous identity in Indonesia: Resource politics and the tribal slot', Comparative Studies in Society and History 42-1:149-79.

Mansur, M. and R. Said (2018). 'Dinamika social-politik kesultanan Jailolo (2002-2017)', Etnohistori: Jurnal Ilmiah Kebudayaan dan Kesejarahan 5-2:136-61.

Mansur, M., K. Sofianto, and D. Mahzuni (2013). 'Otoritas dan legitimasi studi tentang 
kedudukan pemimpin tradisional di Loloda Maluku Utara (1808-1958)', Sosiohumaniora $15^{-1: 64-72 .}$

Müller, S. (2013). 'Adat as a means of unification and its contestation: The case of North Halmahera', in: B. Hauser-Schäublin (ed.), Adat and indigeneity in Indonesia: Culture and entitlements between heteronomy and self-ascription, pp. 99-114. Göttingen: Universitätsverlag Göttingen.

Naidah (1878). 'Geschiedenis van Ternate, in Ternataanschen en Maleischen tekst', with translation and remarks by P. van der Crab, Bijdragen tot de Taal-, Land-en Volkenkunde 26-1:381-493.

Nourse, J.W. (2008). 'Rogue kings and divine queens in Central Sulawesi and GuineaBissau', Indonesia and the Malay World 36-105:235-52.

Platenkamp, J.D. (2013). 'Sovereignty in the North Moluccas: Historical transformations', History and Anthropology 24-2:206-32.

Rahman, A. (2015). 'Struktur sosial politik kerajaan Loloda di antara minoritas Islam dan mayoritas Kristen abad XVII-XX', Buletin Al-Turā̇̇ 21-2:91-112.

Rahman, M. (2006). Mengenal Kesultanan Tidore. Tidore: Lembaga Kesenian Keraton. Sahlins, M. (1985). Islands of history. Chicago: University of Chicago Press.

Sahlins, M. (2008). 'The stranger-king or, elementary forms of the politics of life', Indonesia and the Malay World 36-105:177-99.

Song, S.W.(2020). 'A heavenly nymph married to an Arab sayyid: Stranger-kingship and diarchic divisions of authority as reflected in foundation myths and rituals in North Maluku, Indonesia', Indonesia and the Malay World 140-48:116-35.

Turner, K. (2003). 'Myths and moral authority in Maluku: The case of Ambon', Asian Ethnicity 4-2:241-63.

Tyson, A.D. (2010). Decentralization and adat revivalism in Indonesia: The politics of becoming indigenous. New York: Routledge.

Widjojo, M. (2009). The revolt of Prince Nuku:Cross-cultural alliance-making in Maluku, c. 1780-1810. Leiden: Brill.

Wilson, C. (2008). Ethno-religious violence in Indonesia: From soil to God. London: Routledge Contemporary Southeast Asia series. 